\title{
Tamaricion dalmaticae, a new alliance from the eastern Adriatic
}

\section{Nenad Jasprica ${ }^{1}$}

\section{Keywords:}

tamarisk scrub, Nerio oleandriTamaricetea africanae,

phytosociology, syntaxonomy, new syntaxa, NE Mediterranean.

\section{Ključne besede:}

grmičevje tamariše, Nerio oleandriTamaricetea africanae, fitocenologija, sintaksonomija, novi sintaksoni, severovzhodni Mediteran.
Received: 2. 7. 2015

Revision received: 15.10 .2015

Accepted: 18. 10. 2015

\begin{abstract}
The paper describes the Tamaricion dalmaticae alliance and the Tamaricetum dalmaticae association, a new syntaxa localized under the saline or sub-halophilous conditions within the thermo-mediterranean and meso-mediterranean belts of the eastern Adriatic coast. The Tamaricion dalmaticae alliance is considered analogous to the Western Mediterranean Tamaricion africanae. The Tamaricetum dalmaticae association shows the high ecological amplitude of in terms of moisture. It develops on sandy soils only periodically inundated with sea or brackish waters, as well as on non-flooded areas in south Croatia, Montenegro and NW Albania. In Croatia, Tamaricetum dalmaticae has connections with the halophyte communities of the Sarcocornietea fruticosae and Ammophiletea classes, and the xerophilous ruderal communities of the Artemisietea vulgaris class. The habitats are exposed to disturbances and fragmentation.

\section{Izvleček}

V članku opisujemo zvezo Tamaricion dalmaticae in asociacijo Tamaricetum dalmaticae, nova sintaksona $\mathrm{v}$ slanih ali pol-slanih rastiščnih razmerah $\mathrm{v}$ termomediteranskem in mezo-mediteranskem pasu ob vzhodni Jadranski obali. Zveza Tamaricion dalmaticae je analogna zahodno mediteranski zvezi Tamaricion africanae. Asociacija Tamaricetum dalmaticae ima široko ekološko amplitudo za vlažnost. Razvija se na peščenih tleh, ki so samo občasno poplavljena z morsko ali brakično vodo, pa tudi na nepoplavljenih območjih na južnem Hrvaškem, v Črni gori in v severozahodni Albaniji. Na Hrvaškem je zveza Tamaricetum dalmaticae povezana $\mathrm{z}$ halofitskimi združbami razredov Sarcocornietea fruticosae in Ammophiletea in kserofilnih ruderalnih združb razreda Artemisietea vulgaris. Habitati so pod vplivom motenj in fragmentacije.
\end{abstract}

Nomenclature: Euro+Med PlantBase (www.emplantbase.org, accessed on 21 October 2015), and The Plant List (www.theplantlist.org, accessed on 21 October 2015) for species not included in the Euro+Med PlantBase. 


\section{Introduction}

This new alliance belongs to the class Nerio oleandriTamaricetea africanae Braun-Blanquet \& O. Bolòs 1958 and the order Tamaricetalia africanae Braun-Blanquet \& O. Bolòs 1958 em. Izco, Fernández-González \& A. Molina 1984. The alliance was proposed by Jasprica et al. (2008) as a preliminary concept (nomen provisorium) and without an original diagnosis. Here I perform the formal validation of this alliance according to ICPN (Weber et al. 2000).

\section{Descriptions of the syntaxa}

Nerio oleandri-Tamaricetea africanae Braun-Blanquet \& O. Bolòs 1958

Tamaricetalia africanae Braun-Blanquet \& O. Bolòs 1958 em. Izco, Fernández-González \& A. Molina 1984

Tamaricion dalmaticae Jasprica, Kovačić \& Ruščić, all. nov. hoc loco

Nomenclature type (holotypus hoc loco designatus): Tamaricetum dalmaticae Jasprica in Jasprica 2016 (this paper, see below)

Name-giving species: Tamarix dalmatica

Diagnostic taxon of the alliance: Tamarix dalmatica

The Tamaricion dalmaticae is a new alliance found in the thermo-mediterranean and meso-mediterranean belts on the eastern Adriatic coast. It is, according to our present knowledge, distributed in Croatia, Bosnia and Herzegovina, Montenegro and Albania. We also predict occurrence also in Greece. Associations of the alliance mostly appear under the saline or sub-halophilous conditions. Along other characteristics, this makes the Tamaricion dalmaticae analogous to the Western Mediterranean Tamaricion africanae Braun-Blanquet \& O. Bolòs 1958. Additionally, the Tamaricion parviflorae Kárpáti \& Kárpáti 1961 alliance, originally described for Albania, is defined as tamarisk scrub of the south-west Balkans distribution (e.g. Dring et al. 2002, Rodwell et al. 2002). More recently, the associations of this alliance were classified within Salicion albae Soó 1930, an alliance of riparian forest vegetation consisting of tall willows that grow on floodways that are regularly inundated for long periods each year (Mullaj et al. 2007). However, such vegetation is not developed along Croatian coast of the Adriatic Sea and it seems to be very rare in Montenegro. Finally, it is necessary to group the Tamarix dalmatica vegetation on the eastern Adriatic in a new alliance because the structure of this vegetation is clearly distinct from that of the Tamaricion parviflorae alliance (Kárpáti \& Kárpáti 1961). According to Flora Croatica Database (Nikolić 2015), Tamarix parviflora in Croatia grows only as a cultivated ornamental tree.

\section{Tamaricetum dalmaticae Jasprica, ass. nov. hoc loco}

Nomenclature type relevé (holotypus hoc loco designatus): relevé NJ-NRD 117, Croatia, the Neretva River delta, town of Ploče, SE of town, in the port area (Figure 1), along the Parila Channel; geographic coordinates: $43^{\circ}$ 01' 57.9” N; $17^{\circ} 25^{\prime} 36.9^{\prime \prime}$ E; altitude: $1.5 \mathrm{~m}$ a.s.l.; topography: flat; plot: $10 \mathrm{~m} \times 5 \mathrm{~m}$; vascular plant cover: $90 \%$; average vegetation height: $2 \mathrm{~m}$; substrate: yellow permeable and humus poor sand; sampled by Nenad Jasprica on 28-06-2006; sampling scale: Braun-Blanquet (1964).

Vascular plants composition: Tamarix dalmatica 5, Phleum arenarium 2, Daucus carota 2, Phragmites australis 1, Limbarda crithmoides 1, Elymus pycnanthus 1, Xanthium strumarium 1 (juv.), Salsola soda 1, Elymus farctus +, Cynodon dactylon +, Hordeum murinum ssp. leporinum +, Glycyrrhiza glabra +, Cynanchum acutum + , Dittrrichia viscosa +, Rumex sp. +, Juncus maritimus +, Calystegia sepium +, Cirsium vulgare +, Aristolochia clematitis +, Halimione portulacoides +, Atriplex prostrata +, Polypogon monspeliensis +, Parapholis incurva + .

This association is distributed on sandy soils only periodically inundated with sea or brackish waters, as well as on non-flooded areas in the Neretva River delta, south Croatia. In optimal conditions of development, it is practically impenetrable. This vegetation is in connection with the vast stands of semi-woody shrub and

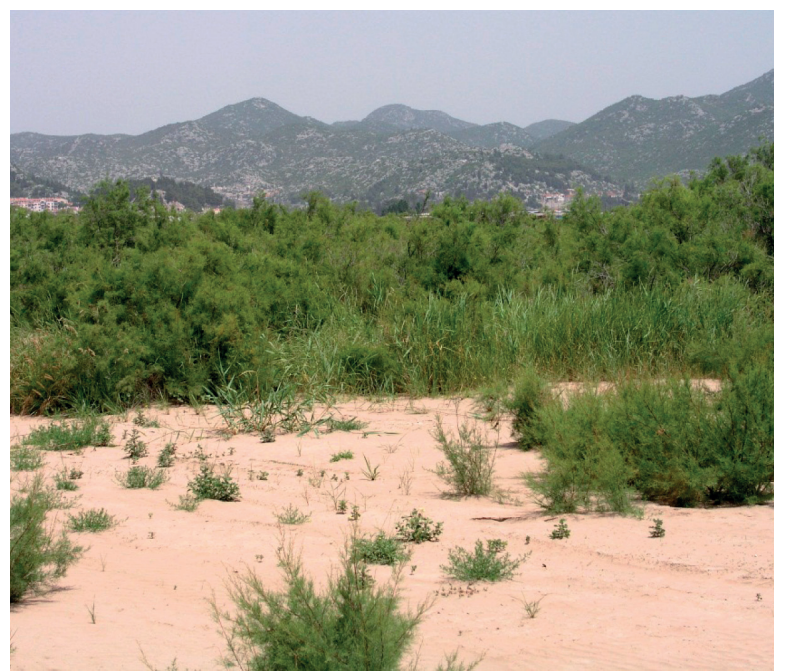

Figure 1. Tamaricetum dalmaticae in the Port of Ploče, south Croatia (photo: N. Jasprica, June 28, 2006).

Slika 1. Tamaricetum dalmaticae v pristanišču Ploče, južna Hrvaška (foto: N. Jasprica, June 28. 6. 2006). 
perennial halophytic communities of Sarcocornietea fruticosae Braun-Blanquet \& Tüxen ex A. Bolòs \& O. Bolòs in A. Bolòs 1950 nom. mut. propos Rivas-Martínez, T.E. Díaz, Fernandez-Gonzales, Izco, Loidi, Lousã \& Penas 2002 and caespitous dune-colonising vegetation of $\mathrm{Am}$ mophiletea Braun-Blanquet \& Tüxen ex Westhoff, Dijk \& Passchier 1946. On the other hand, it borders with xerophilous ruderal vegetation of the Artemisietea vulgaris Lohmeyer, Preising \& Tüxen ex Von Rochow 1951. The association is also found in Montenegro and NW Albania. Some hygrophilic species from Salici purpureaePopuletea nigrae Rivas-Martínez \& Cantó ex Rivas-Martínez, Báscones, T.E. Díaz, Fernández-González \& Loidi 2001 (Salix alba, Populus alba, Fraxinus angustifolia, etc.) were found in the Montenegrin stands. This indicates the high ecological amplitude of the association in terms of moisture. These habitats are often fragmented due to different disturbances, mainly related to reconstructions of the ports (Croatia) or tourism activities (Montenegro).

This association has connections with the Vitici agni-casti-Tamaricetum dalmaticae (Horvatić 1960) corr. Trinajstić 2008 (Trinajstić 2008), which can also be ascribed to the alliance Tamaricion dalmaticae. Although these associations share certain common characteristics, in our opinion the Vitici agni-casti-Tamaricetum dalmaticae association is affected by a decreasing gradient of salinity and an increasing distance from the sea, and by a different granulometry of the substratum. In Croatia, the association is characterized by the high percentage and the greater biomass of the hygrophilous species (e.g. Vitex agnus-castus, Periploca graeca, Phalaroides arundinacea, etc.).

\section{References}

Braun-Blanquet, J. 1964: Pflanzensoziologie. Grundzüge der Vegetationskunde [Plant sociology. Basic course of Vegetation Science]. $3^{\text {rd }}$ ed. Wien-New York: Springer-Verlag.

Dring, J., Hoda, P., Mersinllari, M. Mullaj, A., Pignatti, S. \& Rodwell, J. 2002: Plant Plant communities of Albania - a preliminary overview. Annali di Botanica Nuova Serie 2: 7-30.

Jasprica, N., Ruščić, M. \& Kovačić, S. 2008: Tamaricion dalmaticae Jasprica et al., all. nova, on the southeastern Adriatic coast. Symposium Flora and Vegetation of Slovenia 2008, dedicated to the $70^{\text {th }}$

anniversary of Prof. Tone Wraber and $10^{\text {th }}$ anniversary of the Slovenian Botanical Society, Ljubljana, Slovenia, October 17-18, 2008. Hladnikia 22: 50.

Kárpáti, I. \& Kárpáti, V. 1961: Die zönologischen Verhältnisse der Auenwälder Albaniens [The zonation of of alluvial forests of Albania]. Acta Botanica Academiae Scientiarum Hungaricae 7: 235-301.

Mullaj, A., Vangjeli, J., Peçi, D. \& Imeri, A. 2007: General considerations on the flora and vegetation of Albania's rivers. In Pinna, M., Felice Uricchio, V., Michele Aresta, M. \& Basset, A. (eds.). Rivers and citizens. Cross-border experiences in environmental protection and sustainable development. University of Salento, 17-25.

Nikolić, T. (ed.) 2015: Flora Croatica baza podataka [Flora Croatica Database]. On-Line, URL: http://hirc.botanic.hr/fcd. Botanički zavod, Prirodoslovno-matematički fakultet, Sveučilište u Zagrebu [last accessed on October 21, 2015].

Rodwell, J. R., Schaminee, J. H. J., Mucina, L., Pignatti, S., Dring, J. \& Moss, D. 2002: The diversity of European vegetation. An overview of phytosociological alliances and their relationship to EUNIS habitats. Report EC-LNV 2002/054, Wageningen.

Trinajstić, I. 2008: Biljne zajednice Republike Hrvatske [Plant communities of Croatia]. Akademija šumarskih znanosti, Zagreb.

Weber, H. E., Moravec, J. \& Theurillat, J.-P. 2000: International Code of Phytosociological Nomenclature. $3^{\text {rd }}$ ed. Journal of Vegetation Science 11: 739-768. 